\title{
CONSIDERATION OF THE THERAPEUTIC POTENTIAL OF IRRIGANTS IN ENDODONTIC THERAPY
}

Dajana Nogo-Zivanovic ${ }^{1}$, Ljiljana Bjelovic ${ }^{1}$, Vladimir Ivanovic ${ }^{2}$, Tatjana Kanjevac ${ }^{3}$, Irena Tanaskovic ${ }^{4}$

${ }^{1}$ Department for Restorative Dentistry and Endodontics, Faculty of Medicine, University of East Sarajevo, Foca, Bosnia and Herzegovina ${ }^{2}$ Department of Restorative Odontology and Endodontics, School of Dental Medicine, University of Belgrade, Belgrade, Serbia ${ }^{3}$ Department of Preventive and Pediatric Dentistry, Faculty of Medical Sciences, University of Kragujevac, Kragujevac, Serbia ${ }^{4}$ Department of Histology and Embryology, Faculty of Medical Sciences, University of Kragujevac, Kragujevac, Serbia

\section{RAZMATRANJE TERAPIJSKIH MOGUĆNOSTI IRIGANASA U ENDODONTSKOJ TERAPIJI}

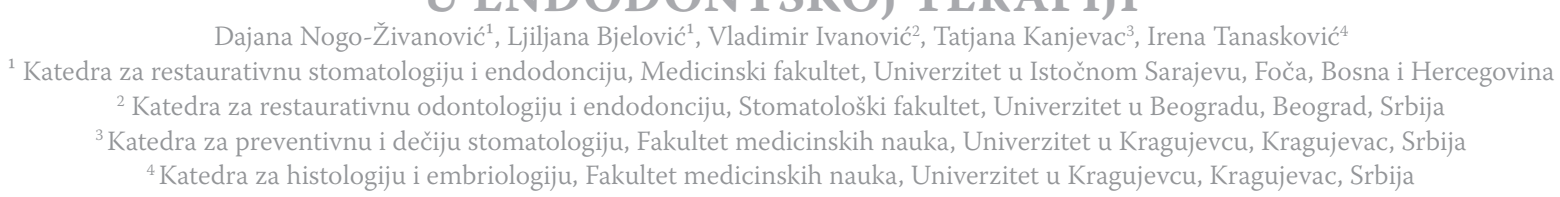

\begin{abstract}
The main objective of endodontic treatment is to remove vital and necrotic remnants of pulp tissue and microorganisms and their toxic products from the root canal. During chemo-mechanical endodontic preparation, a smear layer is formed on the wall of the canals. Due to an inability to remove all tissue remnants and the smear layer from the root canal by mechanical instrumentation, it is necessary to use irrigation to ensure sufficient cleaning and disinfection of the largest part of the root canalicular system. The most commonly used irrigants are sodium hypochlorite ( $\mathrm{Na}$ $O C l)$, ethylenediaminetetraacetic acid (EDTA), citric acid and chlorhexidine (CHX). Recently, the irrigants QMix and $M T A D$ have been introduced to the market. They are a mixture of different components having antimicrobial, organolytic and mineralytic effects on canal detritus and the smear layer. This review article investigates irrigants in terms of the nature of their effect, their efficiency, optimal concentration, and method of use, and the interactions between the irrigants most commonly used in endodontic therapy are discussed, with special emphasis on QMix and MTAD.
\end{abstract}

Keywords: endodontic treatment, smear layer, endodontic irrigants

\section{SAŽETAK}

Osnovni cilj endodontske terapije je uklanjanje vitalnih $i$ nekrotičnih ostataka pulpnog tkiva, mikroorganizama $i$ njihovih toksičnih produkata iz kanala korena zuba. U toku hemo-mehaničke obrade kanala korena na zidovima se formira razmazni sloj. Zbog nemogućnosti da se mehaničkom obradom uklone svi ostaci tkiva $i$ razmazni sloj iz kanala korena, neophodno je koristiti irigaciju, kako bi se obezbedilo čišćenje i dezinfekcija najvećeg dela kanalikularnog sistema korena. Najčešće upotrebljivana sredstva za ispiranje kanala korena su natrijum-hipohlorit ( $\mathrm{NaOCl}$ ), etilendiaminotetraacetatna kiselina (EDTA), limunska kiselina i hlorheksidin (CHX). U novije vreme na tržištu su se pojavili irigansi, kao što su QMix i MTAD. Predstavljaju mešavinu različitih komponenti koje ispoljavaju antimikrobno dejstvo, kao i organo- i mineralolitički efekat na kanalni detritus i razmazni sloj. U ovom preglednom članku razmatran je način dejstva, efikasnost, optimalna koncentracija, način upotrebe i međusobna interakcija najčešće korišćenih iriganasa u endodontskoj terapiji, sa posebnim osvrtom na QMix i MTAD.

Ključne reči: endodontski tretman, razmazni sloj, endodontski irigansi

\section{INTRODUCTION}

The most common aetiological factors causing pulp and periapical diseases are microorganisms. The main objective of endodontic treatment is to remove vital and necrotic remnants of the pulp tissue, microorganisms and their toxic products from the root canal. Due to the anatomical complexity of the root canal system and the presence of numerous isthmi and intercanal communications and pulp-periodontal communications, a significant part of the intracanal area remains inaccessible to the mechanical effects of endodontic instruments. The research of Peters et al. shows that regardless of the technique of preparation, approximately $35 \%$ of the canal surface remains mechanically uninstrumented (1).

During chemo-mechanical preparation of the root canal, a smear layer 1-2 microns thick is produced on the walls. This layer contains remnants of vital and/or necrotic 
pulp tissue, micro-organisms and their toxins and dentin particles of different size (2). The presence of a smear layer on the canal walls may partially or totally block the dentinal tubules and prevent the effects of irrigants and intracanal medicaments, obstruct the adhesion of materials for definitive obturation and provide a potential route for micro leakage (2). It also presents a nutritious foundation for the growth and multiplication of microorganisms. All of these factors lead to the failure of endodontic therapy, which is the reason why the removal of the smear layer is recommended (2).

Due to an inability to completely remove the remains of the residual tissue and smear layer from the root canal by mechanical instrumentation, it is necessary to use irrigation, which ensures cleaning and disinfection of the largest part of the canalicular system $(3,4)$. An ideal irrigant should possess antibacterial and fungicidal effects; not irritate periapical tissue; be chemically stable; possess prolonged antimicrobial activity; be effective in the presence of blood, serum and protein derivatives from the tissue; remove completely the smear layer; possess a low surface tension and the ability to penetrate into the dentinal tubules and disinfect them; not interfere with reparative processes in the periodontal tissue; not overpaint the tooth; not have antigenic, toxic or carcinogenic effects on surrounding vital structures; not have a negative effect on the physical and chemical properties of the dentin; not interfere with the adhesion of materials for the definitive obturation, and be easily prepared and applied to the prepared canal (5).

Currently, there is no single irrigant that meets all of the previously mentioned requirements, so that in everyday clinical practice it is necessary to combine irrigants. The most commonly used irrigants for rinsing the root canal are sodium hypochlorite $(\mathrm{NaOCl})$, ethylenediaminetetraacetic acid (EDTA), citric acid and chlorhexidine (CHX) (6), while recently, irrigants such as QMix and MTAD have been introduced to the market. Both are a mixture of different components designed to dissolve organic and mineral parts of the canal detritus and smear layer, as well as to have antimicrobial effects. The use of MTAD and QMix as final irrigants should simplify the procedure of irrigation, prevent interaction between different irrigants and should not be detrimental to the mechanical, physical and chemical properties of the root canal dentin.

Development of new irrigants, and their use in an appropriate manner, is imperative for successful endodontic treatment. Thanks to the existence of a number of research methods, such as electron microscopy $(7,8,9,10)$, in tests of cytotoxicity $(11,10,12)$ and antibacterial efficacy (13, $14,15,16,17,18)$, today it is possible to evaluate the efficiency of irrigants used in endodontic therapy in a relatively simple way.

This review article presents a brief overview of current knowledge of the effect, efficiency, optimal concentration, method of use and interaction of the most commonly used irrigants in endodontic therapy, with special emphasis on QMix and MTAD.

\section{SODIUM HYPOCHLORITE (NAOCL)}

Sodium hypochlorite is a solution originally used for bleaching and disinfection (19). Due to its strong antimicrobial effect and its ability to dissolve organic tissue, it is the irrigant that is most often used during endodontic therapy $(6,20,21)$. Due to its effect on soft tissue, $\mathrm{NaOCl}$ should be used cautiously, without the risk of transferring the irrigant over the apex. In the case of transfer of the solution onto the periapical tissue, pain can occur, as well as oedema, bleeding and even paraesthesia $(22,23)$. The chemical reaction of $\mathrm{Na}$ $\mathrm{OCl}$ with organic tissue proceeds through three phases. First, saponification of $\mathrm{NaOCl}$ dissolves the fatty acids by converting them into glycerol and fatty acid salts. This is followed by neutralization of amino acids by $\mathrm{NaOCl}$ caused by the formation of water and salt, with the release of hydroxyl ions, which strongly reduces the $\mathrm{pH}$. Finally, the chlorination reaction, when hypochlorous acid from $\mathrm{NaOCl}$ comes into contact with organic tissue, acting as a solvent, leads to the release of chlorine, which reacts with the amino groups of proteins to form chloramine, which interferes with cell metabolism (24). The antibacterial effect of chloramine is based on its inhibitory effect on bacterial enzymes, leading to oxidation of sulphydryl groups (SH). Hypochlorous acid ( $\mathrm{HOCl}-$ ) and hypochlorite ions (OCl-) cause the degradation of amino acids and protein hydrolysis (24). $\mathrm{NaOCl}$ is a strong base with a $\mathrm{pH}$ of 11 , which is the basis of its antimicrobial effect, and its mode of action is similar to that of calcium hydroxide.

For endodontic treatment $\mathrm{NaOCl}$ is used at concentrations ranging from $0.5 \%$ to $6 \%$. In a wide search of the literature, no clear recommendation was found for the best concentration to be used in endodontic therapy. Higher concentrations of $\mathrm{NaOCl}$ dissolve organic tissue better (25), but they have a stronger toxic effect (26). The toxicity of this solution can be overcome by using a lower concentration with prolonged periods of irrigation, and by using larger amounts of irrigants, by which the same antimicrobial efficacy and effect on dissolving organic tissue are achieved as at high concentrations $(24,26-30)$. The effect of $\mathrm{NaOCl}$ may be enhanced by increasing the concentration, heating, using a prolonged period of irrigation and sonic or ultrasonic activation (27).

In the presence of soft and dentin tissue, chlorine is released, but a weakening of the effect of $\mathrm{NaOCl}$ occurs (31-33). Therefore, a continuous renewal of the solution is necessary to ensure efficient disinfection and dissolution of all organic content.

Certain in vitro studies suggest that high concentrations of $\mathrm{NaOCl}$ have a stronger effect on E. faecalis and C. albicans $(28,29,34)$. In contrast, in vivo studies showed that both low and high concentrations have the same efficacy in eliminating microorganisms from the root canal (35). $\mathrm{NaOCl}$ can inactivate bacterial endotoxin, but this effect is much less than its antibacterial effect $(36,37)$. 
By reducing the concentration of the solution and the time of irrigation, the ability of $\mathrm{NaOCl}$ to penetrate into dentinal tubules and disinfect them decreases $(38,39)$. With the addition of surface active substances which reduce the surface tension, the depth of penetration of $\mathrm{NaO}$ $\mathrm{Cl}$ into the tubules and the dissolution rate of the tissue are increased $(4,40)$.

Compared to its superior effect in terms of antimicrobial effects, $\mathrm{NaOCl}$ has a strong cytotoxic effect $(41,42)$.

As a result of collagen and glycosaminoglycan degradation, $\mathrm{NaOCl}$ may affect the hardness, flexural strength and elasticity of the root dentin (43-46).

To be effective on the organic and inorganic components of the smear layer during endodontic treatment, $\mathrm{NaOCl}$ irrigation followed by a final irrigation with EDTA is recommended. In case of contact between $\mathrm{NaOCl}$ and EDTA and their interaction, the loss of NaOCl's active component chlorine occurs, thereby reducing the antimicrobial efficacy of $\mathrm{NaOCl}$ (47), as well as the solubility of vital and/or necrotic tissue (48). This reducing effect may even be caused by low concentrations of EDTA (49, 50). The interaction between $\mathrm{NaOCl}$ and $\mathrm{CHX}$ is spotted, which leads to discoloration of dentin and creation of an orange-brown residue containing para-chloroaniline, which has a carcinogenic effect (51). The interaction between $\mathrm{NaOCl}$ and $\mathrm{CHX}$ and the formation of those residues depends on the concentration of irrigants (52). After root canal irrigation with $\mathrm{NaOCl}$, the root canal should be rinsed with distilled water (49) to prevent or at least to reduce the interaction with other irrigants. Despite the positive properties of $\mathrm{NaOCl}$, including its antimicrobial property, ability to dissolve organic tissues and lubricating effect, it also has some disadvantages, namely, its toxicity, its corrosive effect on endodontic instruments, particularly on those manufactured of nickel-titanium, and its lack of an effect on the inorganic component of the smear layer $(13,53,54)$.

\section{CHLORHEXIDINE (CHX)}

CHX is used in endodontic therapy for irrigation and intracanal medication, in the form of a solution or a gel, in variable concentrations from 0.2 to $2 \%$. It is the most commonly used irrigant after the use of $\mathrm{NaOCl}$ and EDTA (6). $\mathrm{CHX}$ is recommended as an irrigant because of its low toxicity, broad spectrum of antimicrobial effect, and gradual and prolonged effect on microorganisms $(28,55)$.

CHX has wide antimicrobial effects, including effectiveness on G + and G- bacteria and fungi, especially on $E$. faecalis and C. albicans (56). CHX is a positively charged hydrophobic and lipophilic molecule that attaches to negatively charged phosphate groups on the cell wall (57), leading to changes in the osmotic balance of the cell $(58,59)$. The antimicrobial activity of CHX depends on the $\mathrm{pH}$ (optimum $\mathrm{pH}$ of approximately 5.5-7) (60) and on the concentration of the solution (14). Low concentrations of CHX
$(0.2 \%)$ produce a bacteriostatic effect, while high concentrations (2\%) are bactericidal, causing cell damage, coagulation of cytoplasm, and precipitation of proteins and nucleic acids (61). In vivo and in vitro studies indicate that $\mathrm{CHX}$ has an anti-microbial effect similar to that of $\mathrm{NaOCl}$, and it produces a greater effect on E. faecalis and some fusiform bacterial strains present in the infected root canal $(15,28,55,62-64)$.

CHX has the property of substantivity. Due to the cation structure of its molecules it is attached to negatively charged surfaces in the oral cavity, and is continuously released and produces a prolonged antimicrobial activity. The use of CHX may achieve long-term antimicrobial activity for up to 12 weeks (65). Substantivity depends on the presence of the CHX molecule that interacts with dentin (66).

CHX has minimal or no effects on the reduction of lipopolysaccharides (LPS, endotoxin, a component of the outer membrane of G- bacteria), which play a significant role in the pathogenesis of apical periodontitis, causing pain that occurs in cases of infection in the root canal $(67,68)$.

Unlike $\mathrm{NaOCl}, \mathrm{CXH}$ is not capable of dissolving organic tissue, it is relatively safe when used as an irrigant, and it does not cause allergic reactions $(69,70)$.

Due to its broad antimicrobial spectrum, as well as an inability to dissolve organic tissue, it is proposed that CHX should be used as a final irrigant after irrigating with $\mathrm{Na}$ $\mathrm{OCl}$ and EDTA (71). The combination of $\mathrm{NaOCl}$ and $\mathrm{CHX}$ improves antimicrobial efficacy, and the use of CHX as a final irrigant extends its antimicrobial activity, due to its substantivity (72).

If contact occurs accidentally between $\mathrm{CHX}$ and $\mathrm{Na}$ $\mathrm{OCl}$ during irrigation, the formation of an orange-brown residue and the formation of a chemical smear layer occurs, which may exhibit cytotoxic potential $(49,51)$, block the dentinal tubules, impair adhesion of material for the definite obturation $(73,74)$, and cause a colour change of dentin (75-77). When CHX comes into contact with EDTA, the formation of a milky white precipitate occurs as a result of an acid-base reaction (49). To avoid or at least to reduce this formation, it is necessary to prevent mutual contact between the two irrigants by thorough rinsing of the root canal using distilled water (49).

\section{ETHYLENEDIAMINETETRAACETIC ACID (EDTA)}

In addition to $\mathrm{NaOCl}$, one of the most commonly used irrigants is EDTA (6). It is used for the dissolution of the inorganic part of the smear layer. Its mineralytic effect is expressed through its ability to bind divalent and trivalent metal ions, such as $\mathrm{Ca}^{2+}$ and $\mathrm{Fe}^{3+}$ One molecule of EDTA binds a maximum of four calcium ions, which provides a relatively stable, water-soluble chelated complex. It is usually used in concentrations of $15-17 \%$, at a $\mathrm{pH}$ of 7-8 (6, 71). A final root canal irrigation with $5 \mathrm{ml}$ 17\% EDTA for 3 
minutes effectively removes the smear layer (7). Although a concentration of $17 \%$ is sufficient and commonly used to remove the smear layer, some studies have shown that lower concentrations of EDTA $(15 \%, 10 \%, 5 \%, 1 \%)$, after initial irrigation with $\mathrm{NaOCl}$, also effectively remove the smear layer (78).

In addition to the effect on the smear layer, EDTA can cause demineralization of dentin. With increasing concentrations, $\mathrm{pH}$ levels and the time of the exposure of dentin to EDTA, the degree of dentin demineralization increases. Application of $10 \mathrm{ml} \mathrm{17 \%} \mathrm{EDTA} \mathrm{for} \mathrm{one} \mathrm{min} \mathrm{effectively}$ removes the smear layer. If the exposure time is extended to $10 \mathrm{~min}$, a severe erosion of the peritubular and intratubular dentin may occur (79). A study that examined the effect of EDTA and the combination of EDTA and $\mathrm{NaOCl}$ on dentin in elderly and young patients showed that it is necessary to avoid prolonged exposure of old dentin to the combination of those irrigants, to reduce the risk of excessive erosion and demineralization. Both irrigants led to an increased brittleness of already sclerotic root dentin, and consequently increased the incidence of cracks during the functional loading of the root (80).

Chelating agents significantly reduce the micro hardness and pressure resistance of dentin, and this effect is most pronounced when EDTA is used as an irrigant, either alone or in combination with $2.5 \% \mathrm{NaOCl}(80)$.

Chelating agents also reduce the resistance of the root to fracture, and the use of 17\% EDTA for $10 \mathrm{~min}$ and 1\% $\mathrm{NaOCl}$ for one minute reduces the resistance to root fracture by approximately 1.5 times, while lower concentrations of EDTA (5\%) and shorter exposure times (one minute) cause a smaller reduction in resistance (81).

As a result of the removal of the smear layer and demineralization of dentin, EDTA causes changes in the permeability of dentin by formation of certain precipitates and by partial or complete obturation of the root dentin tubules $(82,83)$. Therefore, complete removal of residual EDTA solution is necessary, using an application of either deion$\mathrm{ized} /$ distilled water or saline solution.

\section{CITRIC ACID}

Citric acid is a weak organic acid and is used to remove the inorganic part of the smear layer after initial rinsing of the canal (8). It is used at a concentration of $1-50 \%$, but the most commonly used concentration is $10 \%$.

The effect of $\mathrm{H}+$ ions from the citric acid leads to the release of ions from the surface of hydroxyapatite dentin crystals, forming soluble chelate complexes $(84,85)$. The effectiveness of citric acid may be improved by increasing the concentration (86), reducing the $\mathrm{pH}(87)$ and extending the time of use (88).

In comparison with EDTA, citric acid removes the smear layer in an inappropriate way (89) and has a more pronounced erosive effect on root dentin (90). In a study by De-Deus and his associates in which they exposed dentin to $1 \%$ citric acid, $17 \%$ EDTA and 17\% EDTAC, citric acid showed the strongest decalcification effect on root dentin (91).

If $19 \%$ citric acid is used, it significantly reduces the micro hardness of dentin compared to 17\% EDTA (92). Further, citric acid, like EDTA, has poor antimicrobial activity $(16,93,94)$.

In vitro studies indicate some cytotoxicity of citric acid. However, $10 \%$ citric acid shows a significant biocompatibility compared to 17\% EDTA and 17\% EDTA-T (11). Using $\mathrm{NaOCl}$ and citric acid does not cause the formation of precipitates (49).

\section{MTAD}

MTAD is the first irrigant on the market that can simultaneously perform disinfection of the canal system and remove the smear layer (17). It is a mixture of antibiotics (doxycycline, 3\%), chelating agents (4.25\% citric acid) and a detergent (Tween 80). It is sold under the name of the manufacturer, BioPure MTAD (Dentsply Tulsa Dental, Tulsa, OK, USA) and is prepared by mixing the liquid contained in the syringe with the powder contained in the bottle, immediately prior to its application. As a mixture, it has a shelf life of $48 \mathrm{~h}$, which is considerably shorter than those of other irrigants used in endodontic practice (95). It does not possess the ability to dissolve organic tissue. It is recommended for use as the final irrigant after complete chemo-mechanical treatment of the root canal $(17,96--$ 99). The irrigation protocol recommends the use of MTAD for $5 \mathrm{~min}$, after an initial root canal irrigation with $1.3 \%$ $\mathrm{NaOCl}$ for 20 minutes (100).

In the available literature, there are no data on the exact mechanism of the effects of MTAD. The ability to remove the smear layer is attributed to the effect of citric acid and doxycycline, while its antibacterial effect is due to the effect of doxycycline, which is a tetracycline with a broad antibacterial spectrum, and exerts its bacteriostatic effect by inhibiting protein synthesis (101).

Despite the fact that MTAD has proven effectiveness against $E$. faecalis $(17,96,97,102)$, as well as effectiveness in the removal of the smear layer (103-105), in subsequent studies its antimicrobial efficiency has been challenged (106-108). When MTAD is applied after an initial irrigation with $1.3 \% \mathrm{NaOCl}$, its antimicrobial effect is reduced, probably due to oxidation of MTAD under the influence of $\mathrm{NaOCl}$ (109). The antibacterial efficiency of MTAD may be reduced due to the presence of dentin and serum albumins from the root canal (110). Its efficiency in eliminating E. faecalis biofilm is relatively low $(100,111,112)$. E. faecalis biofilm is more difficult to remove and is more resistant to the effects of antimicrobials than planktonic bacteria (113). MTAD removes the smear layer more efficiently than EDTA, particularly in the apical third of the canal (114), where it causes less pronounced erosive changes to the dentin (104). 
The low surface tension of MTAD (34.5 mJ / m2) (115) may provide a more complete contact of the irrigant with the dentin of the root canal, extending its ability to penetrate deeper into dentinal tubules, ensuring a more efficient removal of the smear layer, disinfecting canal walls and leading to better and easier diffusion of the components of intracanal medicaments.

MTAD has a lower cytotoxicity than most commonly used irrigants and intracanal medicaments in endodontic therapy, such as eugenol, hydrogen peroxide (3\% solution), $\mathrm{Ca}(\mathrm{OH})_{2}$ paste, $\mathrm{NaOCl}(5.25 \%)$ and EDTA, while its cytotoxic effect is greater than that of lower concentrations of $\mathrm{NaOCl}(2.63 \%, 1.31 \%, 0.66 \%)$ (116).

There is only one in vivo study showing that MTAD causes postoperative pain during endodontic therapy (117). Further studies are needed to confirm the efficacy of MTAD solution in in vivo conditions as well.

\section{QMix}

QMix is a new irrigant recently introduced to the market. In addition to a detergent, CHX and EDTA are also included in its composition (114). It combines the advantages of EDTA, contains a surfactant plus CHX and has a slight effect on dentin. Based on the manufacturer's recommendation, it should be used as a final irrigant for a period of $60-90$ s, following a $6.15 \% \mathrm{NaOCl}$ irrigation. If $\mathrm{NaOCl}$ is used during the chemo-mechanical preparation, it is necessary to rinse the canal with saline or distilled water before using QMix.

A large number of studies indicate that QMix has the same efficiency for removal of the smear layer as EDTA $(18,9)$, and it exhibits a lower erosive effect on dentin (118). Studies by Dai et al. (114) and Eliot et al. (9) indicated that QMix removes the smear layer more effectively than EDTA.

QMix effectively eliminates E. faecalis, eroding its biofilm more quickly than $1 \% \mathrm{NaOCl}$ and $2 \% \mathrm{CHX}$ and to the same extent as $2 \% \mathrm{NaOCl}(18)$. The bactericidal effect of QMix on a one-day old bacterial biofilm is the same as the effect of $6 \% \mathrm{NaOCl}$ and is more efficient than a lower concentration of $\mathrm{NaOCl}$ or $2 \%$ CHX $(119,120)$.

In studies in which the ability of QMix to penetrate dentinal tubules was tested, it was observed that QMix may present its antimicrobial activity at the same depth as $6 \% \mathrm{NaOCl}$, within three minutes (119-121). Exposure of dentin tubules to QMix for one minute is more effective than using 2\% CHX for three minutes or using lower concentrations of $\mathrm{NaOCl}(120)$. When the smear layer is present, the bactericidal effect of QMix inside the dentinal tubules is greater after exposure to $6 \% \mathrm{NaOCl}$ for ten minutes than after the combination of $6 \% \mathrm{NaOCl}, 17 \%$ EDTA and $2 \%$ CHX (121).

In addition to efficient removal of the smear layer, QMix increases the humidity of dentin more than EDTA, which has a poorer wetting power (122); this is probably due to the effect of the detergent in the QMix.
Table 1. Characteristics of endodontic irrigants

\begin{tabular}{|c|c|}
\hline $\mathrm{NaOCl}$ & $\begin{array}{l}\text { - effective antimicrobial agent } \\
\text { - current irrigant of choice } \\
\text { - organic tissue solvent } \\
\text { - lubricates } \\
\text { - toxic } \\
\text { - corrosive effect } \\
\text { - not substantive } \\
\text { - removes only the organic part of the smear layer }\end{array}$ \\
\hline CHX & $\begin{array}{l}\text { - wide range of antimicrobial effects against G + and G- } \\
\text { bacteria and fungi } \\
\text { - substantivity in dentin for up to } 12 \text { weeks } \\
\text { - dentin components, inflammatory exudate may in- } \\
\text { hibit the antibacterial activity } \\
\text { - no ability to dissolve organic or inorganic tissue } \\
\text { - biocompatibility }\end{array}$ \\
\hline EDTA & $\begin{array}{l}\text { - effectively removes the smear layer after the initial } \\
\mathrm{NaOCl} \text { irrigation } \\
\text { - demineralization of dentin }\end{array}$ \\
\hline $\begin{array}{c}\text { Citric } \\
\text { acid }\end{array}$ & $\begin{array}{l}\text { - less removal of the smear layer compared with EDTA } \\
\text { - stronger erosive effect on the root canal dentin com- } \\
\text { pared to EDTA }\end{array}$ \\
\hline MTAD & $\begin{array}{l}\text { - antimicrobial properties } \\
\text { - effective solution for removal of the smear layer when } \\
\text { used along with } \mathrm{NaOCl} \\
\text { - less adverse effects on dentinal structure } \\
\text { - good biocompatibility } \\
\text { - no dissolution of organic tissue } \\
\text { - high cost } \\
\text { - reduced shelf life }\end{array}$ \\
\hline QMix & $\begin{array}{l}\text { - antibacterial efficacy } \\
\text { - effective solution for removal of the smear layer when } \\
\text { used along with } \mathrm{NaOCl} \\
\text { - ready for use, fast working } \\
\text { - less demineralization of dentin compared to EDTA }\end{array}$ \\
\hline
\end{tabular}

QMix has a lower cytotoxicity than 17\% EDTA, 2\% $\mathrm{CHX}$ and 3\% $\mathrm{NaOCl}$ (123). Unlike $\mathrm{NaOCl}$, QMix leads to cell death more slowly, without any cell lysis (124). Currently, there are no clinical studies investigating the efficacy of QMix as a final irrigant.

During the application of QMix there is no development of a white precipitate, which typically occurs using a mixture of EDTA and CHX, nor is there formation of an orange-brown residue resulting from combining $\mathrm{NaOCl}$ and CHX (18). This is due to its uniform chemical composition.

\section{CONCLUSION}

In everyday clinical practice, the most frequently used irrigant is sodium hypochlorite, which despite its organolitic and antibacterial properties, does not completely remove the smear layer. To completely remove the smear layer, it is necessary to combine $\mathrm{NaOCl}$ with EDTA or another chelating agent, which act on the inorganic mineral component of the smear layer. In everyday clinical practice, a final irrigation with CHX is recommended because of its property of substantivity and of providing a prolonged an- 
timicrobial effect after completion of the biomechanical preparation of the root canal.

By eliminating some of the drawbacks of currently used irrigants, a new generation of irrigants, such as MTAD and QMix, have appeared, whose application is the subject of our interest. These irrigants, in addition to having an impact on the smear layer, possess the ability to disinfect root canals. Although incapable of dissolving organic tissue, their use as the final canal irrigant is recommended, but only after prior irrigation with $\mathrm{NaOCl}$ has been completed.

Future research should focus on finding an irrigant that has the ability to dissolve tissue, remove the smear layer and exert an antibacterial effect.

\section{ACKNOWLEDGMENTS AND FUNDING}

We are grateful to the Faculty of Medical Sciences, University of Kragujevac, Serbia, for their financial and logistical support and for providing necessary guidance concerning project implementation. This work was supported by the Internal Project of the Faculty of Medical Sciences, University of Kragujevac, Serbia (JP 06/2016).

\section{REFERENCES}

1. Peters OA, Schönenberger K, Laib A. Effects of four $\mathrm{Ni}$-Ti preparation techniques on root canal geometry assessed by micro computed tomography. Int Endod J 2001; 34:221-30.

2. Violich DR, Chandler NP. The smear layer in endodontics - a review. Int Endod J 2010; 43:2-15.

3. Shen Y, Gao Y, Lin J, Ma J, Wang Z, Haapasalo M. Methods and models to study irrigation. Endod Topics 2012; 27:3-34.

4. Haapasalo M, Shen Y, Qian W, Gao Y. Irrigation in endodontics. Dent Clin North Am 2010; $\overline{54: 291-312 . ~}$

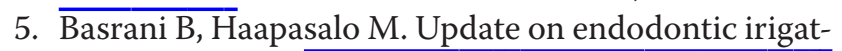
ing solutions. Endod Topics 2012; 27:74-102.

6. Dutner J, Mines P, Anderson A. Irrigation trends among American Association of Endodontists members: a web-based survey. J Endod 2012; 38:37-40.

7. Mello I, Kammerer BA, Yoshimoto D, Macedo MC, Antoniazzi JH. Influence of final rinse technique on ability of ethylenediaminetetraacetic acid of removing smear layer. J Endod 2010; 36:512-4.

8. Herrera DR, Santos ZT, Tay LY, Silva EJ, Loguercio AD, Gomes BP. Efficacy of different final irrigant activation protocols on smear layer removal by EDTA and citric acid. Microsc Res Tech 2013; 76:364-9.

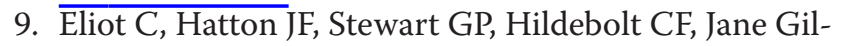
lespie M, Gutmann JL. The effect of the irrigant QMix on removal of canal wall smear layer: an ex vivo study. Odontology 2014; 102:232-40.
10. Kanjevac T, Tanasković I. The application of transmission electron microscopy as a method of characterization of cell populations. REDEOR, Venice, Italy, March 24-27, 2015. Abstract book, S3

11. Malheiros CF, Marques MM, Gavini G. In vitro evaluation of the cytotoxic effects of acid solutions used as canal irrigants. J Endod 2005; 31:746-8.

12. Kanjevac T, Milovanovic M, Milosevic-Djordjevic O, Tesic Z, Ivanovic M, Lukic A. Cytotoxicity of glass ionomer cement on human exfoliated deciduous teeth stem cells correlates with released Fluoride, Strontium and Aluminium ion concetrations. Arch Biol Sci 2015; 67:619-30.

13. Marais JT, Williams WP. Antimicrobial effectiveness of electro chemically activated water as an endodontic irrigation solution. Int Endod J 2001; 34:237-43.

14. Basrani B, Tjaderhane L, Santos JM, Pascon E, Grad $\mathrm{H}$, Lawrence HP, et al. Efficacy of chlorhexidine and calcium hydroxide containing medicaments against Enterococcus faecalis in vitro. Oral Surg Oral Med Oral Pathol Oral Radiol Endod 2003; 96: 618-24.

15. Vianna ME, Gomes BP, Berber VB, Zaia AA, Ferraz CC, de Souza Filho FJ. In vitro evaluation of the antimicrobial activity of chlorhexidine and sodium hypochlorite. Oral Surg Oral Med Oral Pathol Oral Radiol Endod 2004; 97:79-84.

16. Arias-Moliz MT, Ferrer-Luque CM, Espigares-García M, Baca P. Enterococcus faecalis biofilms eradication by root canal irrigants. J Endod 2009; 35:711-4.

17. Torabinejad M, Shabahang S, Aprecio RM, Ketterin JD. The antimicrobial effect of MTAD: an in vitro investigation. J Endod 2003; 29:400-3.

18. Stojicic S, Shen Y, Qian W, Johnson B, Haapasalo M. Antibacterial and smear layer removal ability of a novel irrigant, QMiX. Int Endod J 2012; 45:363-71.

19. McDonnell G, Russell AD. Antiseptics and disinfectants: activity, action, and resistance. Clin Microbiol Rev 1999; 12:147-79.

20. Slaus G, Bottenberg P. A survey of endodontic practice amongst Flemish dentists. Int Endod J 2002; 35:759-67.

21. Clarkson RM, Podlich HM, Savage NW, Moule AJ. A survey of sodium hypochlorite use by general dental practitioners and endodontists in Australia. Aust Dent J 2003; 48:20-6.

22. Behrents KT, Speer ML, Noujeim M. Sodium hypochlorite accident with evaluation by cone beam computed tomography. Int Endod J 2012; 45:492-8.

23. Kleier DJ, Averbach RE, Mehdipour O. The sodium hypochlorite accident: experience of diplomates of the American Board of Endodontics. J Endod 2008; 34:1346-50.

24. Estrela C, Barbin E, Spanó J, Marchesan M, Pécora J. Mechanism of action of sodium hypochlorite. Braz Dent J 2002; 13:113-7.

25. Hand RE, Smith ML, Harrison JW. Analysis of the effect of dilution on the necrotic tissue dissolution property of sodium hypochlorite. J Endod 1978; 4:60-4. 
26. Spangberg L, Engström B, Langeland K. Biologic effects of dental materials. 3.Toxicity and antimicrobial effect of endodontic antiseptics in vitro. Oral Surg Oral Med Oral Pathol 1973; 36:856-71.

27. Stojicic S, Zivkovic S, Qian W, Zhang H, HaapasaloM. Tissue dissolution by sodium hypochlorite: effect of concentration, temperature, agitation and surfactant. J Endod 2010; 36: 1558-62.

28. Gomes BP, Ferraz CC, Vianna ME, Berber VB, Teixeira FB, Souza-Filho FJ. In vitro antimicrobial activity of several concentrations of sodium hypochlorite and chlorhexidine gluconate in the elimination of Enterococcus faecalis. Int Endod J 2001; 34:424-8.

29. Radcliffe CE, Potouridou L, Qureshi R, Habahbeh N, Qualtrough A, Worthington $\mathrm{H}$, et al. Antimicrobial activity of varying concentrations of sodium hypochlorite on the endodontic microorganisms Actinomyces israelii, A. naeslundii, Candida albicans and Enterococcus faecalis. Int Endod J 2004; 37:438-46.

30. Siqueira JF, Rôças IN, Favieri A, Lima KC. Chemomechanical reduction of the bacterial population in the root canal after instrumentation and irrigation with $1 \%, 2.5 \%$, and $5.25 \%$ sodium hypochlorite. J Endod 2000; 26:331-4.

31. Moorer WR, Wesselink PR. Factors promoting the tissue dissolving capability of sodium hypochlorite. Int Endod J 1982; 15:187-96.

32. Slutzky-Goldberg I, Hanut A, Matalon S, Baev V, Slutzky H. The effect of dentin on the pulp tissue dissolution capacity of sodium hypochlorite and calcium hydroxide. J Endod 2013; 39:980-3.

33. Haapasalo HK, Sirén EK, Waltimo TM, Ørstavik D, Haapasalo MP. Inactivation of local root canal medicaments by dentine: an in vitro study. Int Endod J 2000; 33:126-31.

34. Waltimo TM, Ørstavik D, Sirén EK, Haapasalo MP. In vitro susceptibility of Candida albicans to four disinfectants and their combinations. Int Endod J 1999; 32:421-9.

35. Byström A, Sundqvist G. The antibacterial action of sodium hypochlorite and EDTA in 60 cases of endodontic therapy. Int Endod J 1985; 18:35-40.

36. Martinho FC, Gomes BP. Quantification of endotoxins and cultivable bacteria in root canal infection before and after chemomechanical preparation with 2.5\% sodium hypochlorite. J Endod 2008; 34:268-72.

37. Vianna ME, Horz HP, Conrads G, Zaia AA, SouzaFilho FJ, Gomes BP. Effect of root canal procedures on endotoxins and endodontic pathogens. Oral Microbiol Immunol 2007; 22:411-8.

38. Kuga MC, Gouveia-Jorge É, Tanomaru-Filho M, Guerreiro-Tanomaru JM, Bonetti-Filho I, Faria G. Penetration into dentin of sodium hypochlorite associated with acid solutions. Oral Surg Oral Med Oral Pathol Oral Radiol Endod 2011; 112:155-9.

39. Zou L, Shen Y, Li W, Haapasalo M. Penetration of sodium hypochlorite into dentin. J Endod 2010; 36:793-6.
40. Cameron JA. The effect of a fluorocarbon surfactant on the surface tension of the endodontic irrigant, sodium hypochlorite. A preliminary report. Aust Dent J 1986; 31:364-8.

41. Barnhart BD, Chuang A, Lucca JJ, Roberts S, Liewehr F, Joyce AP. An in vitro evaluation of the cytotoxicity of various endodontic irrigants on human gingival fibroblasts. J Endod 2005; 31:613-5.

42. Alaçam T, Omürlü H, Ozkul A, Görgül G, Misirligil A. Cytotoxicity versus antibacterial activity of some antiseptics in vitro. J Nihon Univ Sch Dent 1993; 35:22-7.

43. Zaparolli D, Saquy PC, Cruz-Filho AM. Effect of sodium hypochlorite and EDTA irrigation, individually and in alternation, on dentin microhardness at the furcation area of mandibular molars. Braz Dent J 2012; 23:654-8.

44. Grigoratos D, Knowles J, Ng YL, Gulabivala K. Effect of exposing dentine to sodium hypochlorite $\overline{\text { and }}$ calcium hydroxide on its flexural strength and elastic modulus. Int Endod J 2001; 34:113-9.

45. Marending M, Paqué F, Fischer J, Zehnder M. Impact of irrigant sequence on mechanical properties of human root dentin. J Endod 2007; 33:1325-8.

46. Oyarzún A, Cordero AM, Whittle M. Immunohistochemical evaluation of the effects of sodium hypochlorite on dentin collagen and glycosaminoglycans. J Endod 2002; 28:152-6.

47. Grawehr M, Sener B, Waltimo T, Zehnder M. Interactions of ethylenediamine tetraacetic acid with sodium hypochlorite in aqueous solutions. Int Endod J 2003; 36:411-7.

48. Irala LE, Grazziotin-Soares R, Salles AA, Munari AZ, Pereira JS. Dissolution of bovine pulp tissue in solutions consisting of varying $\mathrm{NaOCl}$ concentrations and combined with EDTA. Braz Oral Res 2010; 24:271-6.

49. Prado M, Santos Júnior HM, Rezende CM, Pinto AC, Faria RB, Simão RA, et al. Interactions between irrigants commonly used in endodontic practice: a chemical analysis. J Endod 2013; 39:505-10.

50. Clarkson RM, Podlich HM, Moule AJ. Influence of ethylenediaminetetraacetic acid on the active chlorine content of sodium hypochlorite solutions when mixed in various proportions. J Endod 2011; 37:538-43.

51. Cintra LT, Watanabe S, Samuel RO, da Silva Facundo AC, de Azevedo Queiroz IO, Dezan-Júnior E, et al. The use of $\mathrm{NaOCl}$ in combination with $\mathrm{CHX}$ produces cytotoxic product. Clin Oral Investig 2014; 18:935-40.

52. Gasic J, Popovic J, Zivković S, Petrovic A, Barac R, Nikolic M. Ultrastructural analysis of the root canal walls after simultaneous irrigation of different sodium hypochlorite concentration and $0.2 \%$ chlorhexidine gluconate. Microsc Res Tech 2012;75:1099-103.

53. McComb D, Smith DC. A preliminary scanning electron microscopic study of root canals after endodontic procedures. J Endod 1975; 1:238-42. 
54. Gernhardt CR, Eppendorf K, Kozlowski A, Brandt M. Toxicity of concentrated sodium hypochlorite used as an endodontic irrigant. Int Endod J 2004; 37:272-80.

55. Jeansonne MJ, White RR. A comparison of $2.0 \%$ chlorhexidine gluconate and $5.25 \%$ sodium hypochlorite as antimicrobial endodontic irrigants. J Endod 1994; 20:276-8.

56. Gomes BP, Vianna ME, Zaia AA, Almeida JF, SouzaFilho FJ, Ferraz CC. Chlorhexidine in endodontics. Braz Dent J 2013; 24:89-102.

57. Gomes BP, Souza SF, Ferraz CC, Teixeira FB, Zaia AA, Valdrighi L, et al. Effectiveness of $2 \%$ chlorhexidine gel and calcium hydroxide against Enterococcus faecalis in bovine root dentine in vitro. Int Endod J 2003; 36:267-75.

58. Hugo WB, Longworth AR. The effect of chlorhexidine on the electrophoretic mobility, cytoplasmic constituents, dehydrogenase activity and cell walls of Escherichia coli and Staphylococcus aureus. J Pharm Pharmacol 1966; 18:569-78.

59. Hugo W, Longworth A. Some aspects of the mode of action of chlorhexidine. J Pharm Pharmaco 1964; 16:751-8.

60. Siqueira JF Jr, Paiva SS, Rôças IN. Reduction in the cultivable bacterial populations in infected root canals by a chlorhexidine-based antimicrobial protocol. J Endod 2007; 33:541-7.

61. Jones CG. Chlorhexidine: is it still the gold standard? Periodontol 2000 1997; 15:55-62.

62. Gomes BP, Vianna ME, Matsumoto CU, Rossi V de P, Zaia AA, Ferraz CC, et al. Disinfection of guttapercha cones with chlorhexidine and sodium hypochlorite. Oral Surg Oral Med Oral Pathol Oral Radiol Endod 2005; 100:512-7.

63. Siqueira JF Jr, Rocas IN, Paiva SS, Guimaraes-Pinto T, Magalhaes KM, Lima KC. Bacteriologic investigation of the effects of sodium hypochlorite and chlorhexidine during the endodontic treatment of teeth with apical periodontitis. Oral Surg Oral Med Oral Pathol Oral Radiol Endod 2007; 104:122-30.

64. Ercan E, Ozekinci T, Atakul F, Gül K. Antibacterial activity of $2 \%$ chlorhexidine gluconate and $5.25 \%$ sodium hypochlorite in infected root canal: in vivo study. J Endod 2004; 30:84-7.

65. Rosenthal S, Spangberg L, Safavi K. Chlorhexidine substantivity in root canal dentin. Oral Surg Oral Med Oral Pathol Oral Radiol Endod 2004; 98:488-92.

66. Mohammadi Z, Abbott PV. The properties and applications of chlorhexidine in endodontics. Int Endod J 2009; 42:288-302.

67. Buck RA, Cai J, Eleazer PD, Staat RH, Hurst HE. Detoxification of endotoxin by endodontic irrigants and calcium hydroxide. J Endod 2001; 27:325-7.

68. Gomes BP, Martinho FC, Vianna ME. Comparison of $2.5 \%$ sodium hypochlorite and $2 \%$ chlorhexidine gel on oral bacterial lipopolysaccharide reduction from primarily infected root canals. J Endod 2009; 35:1350-3.
69. Okino LA, Siqueira EL, Santos M, Bombana AC, Figueiredo JA. Dissolution of pulp tissue by aqueous solution of chlorhexidine digluconate and chlorhexidine digluconate gel. Int Endod J 2004; 37:38-41.

70. Hülsmann M, Rödig T, Nordmeyer S. Complications during root canal irrigation. Endod Topics 2007; 16:27-63.

71. Zehnder M. Root canal irrigants. J Endod 2006; 32:389-98.

72. Vianna ME, Gomes BPFA. Efficacy of sodium hypochlorite combined with chlorhexidine against Enterococcus faecalis in vitro. Oral Surg Oral Med Oral Pathol Oral Radiol Endod 2009; 107:585-9.

73. Vivacqua-Gomes N, Ferraz CC, Gomes BP, Zaia AA, Teixeira FB, Souza-Filho FJ. Influence of irrigants on the coronal microleakage of laterally condensed gutta-percha root fillings. Int Endod J 2002; 35:791-5.

74. Do Prado M, Simao RA, Gomes BP. Evaluation of different irrigation protocols concerning the formation of chemical smear layer. Microsc Res Tech 2013; 76:196-200.

75. Basrani B, Lemonie C. Chlorhexidine gluconate. Aust Endod J 2005; 31:48-52.

76. Akisue E, Tomita VS, Gavini G, Poli de Figueiredo JA. Effect of the combination of sodium hypochlorite and chlorhexidine on dentinal permeability and scanning electron microscopy precipitate observation. J Endod 2010; 36:847-50.

77. Bui TB, Baumgartner JC, Mitchell JC. Evaluation of the interaction between sodium hypochlorite and chlorhexidine gluconate and its effect on root dentin. J Endod 2008; 34: 181-5.

78. Sen BH, Ertürk O, Pişkin B. The effect of different concentrations of EDTA on instrumented root canal walls. Oral Surg Oral Med Oral Pathol Oral Radiol Endod 2009; 108:622-7.

79. Calt S, Serper A. Time-dependent effects of EDTA on dentin structures. J Endod 2002; 28:17-9.

80. Ozdemir HO, Buzoglu HD, Çalt S, Çehreli ZC, Varol E, Temel A. Chemical and ultramorphological effects of ethylenediaminetetraacetic acid and sodium hypochlorite on young and old root canal dentin. J Endod 2012; 38:204-8.

81. Uzunoglu E, Aktemur S, Uyanik MO, Durmaz V, Nagas E. Effect of ethylenediaminetetraacetic acid on root fracture with respect to concentration at different time exposures. J Endod 2012; 38:1110-3.

82. Fogel H, Pashley D. Dentin permeability: effects of endodontic procedures on root slabs. J Endod 1990; 16:442-5.

83. Guignes P, Faure J, Maurette A. Relationship between endodontic preparations and human dentin permeability measured in situ. J Endod 1996; 22:60-7.

84. Papagianni M. Advances in citric acid fermentation by Aspergillus niger: Biochemical aspects, membrane transport and modeling. Biotechnol Adv 2007; 25:244-63. 
85. Dorozhkin SV. Surface Reactions of Apatite Dissolution. J Colloid Interface Sci 1997; 191:489-97.

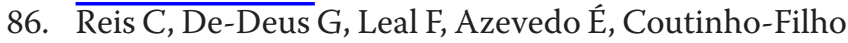
T, Paciornik S. Strong effect on dentin after the use of high concentrations of citric acid: an assessment with co-site optical microscopy and ESEM. Dent Mater 2008; 24:1608-15.

87. Haznedaroglu F. Efficacy of various concentrations of citric acid at different $\mathrm{pH}$ values for smear layer removal. Oral Surg Oral Med Oral Pathol Oral Radiol Endod 2003; 96:340-4.

88. Machado-Silveiro LF, González-López S, GonzálezRodríguez MP . Decalcification of root canal dentine by citric acid, EDTA and sodium citrate. Int Endod J 2004; 37:365-9.

89. Khademi A, Feizianfard M. The effect of EDTA and citric acid on smear layer removal of mesial canals of first mandibular molars, a scanning electron microscopic study. J Res Med Sci 2004; 9:80-8.

90. Qian W, Shen Y, Haapasalo M. Quantitative analysis of the effect of irrigant solution sequences on dentin erosion. J Endod 2011; 37:1437-41.

91. De-Deus G, Reis C, Fidel S, Fidel RA, Paciornik S. Longitudinal and quantitative evaluation of dentin demineralization when subjected to EDTA, EDTAC, and citric acid: a co-site digital optical microscopy study. Oral Surg Oral Med Oral Pathol Oral Radiol Endod 2008; 105:391-7.

92. Eldeniz AU, Erdemir A, Belli S. Effect of EDTA and citric acid solutions on the microhardness and the roughness of human root canal dentin. J Endod 2005; 31:107-10.

93. Siqueira JF Jr, Batista MM, Fraga RC, de Uzeda M. Antibacterial effects of endodontic irrigants on blackpigmented gram-negative anaerobes and facultative bacteria. J Endod 1998; 24:414-6.

94. Georgopoulou M, Kontakiotis E, Nakou M. Evaluation of the antimicrobial effectiveness of citric acid and sodium hypochlorite on the anaerobic flora of the infected root canal. Int Endod J 1994; 27:139-43.

95. Clarkson RM, Moule AJ, Podlich HM. The shelf-life of sodium hypochlorite irrigating solutions. Aust Dent J 2001; 46:269-76.

96. Shabahang S, Torabinejad M. Effect of MTAD on Enterococcus faecalis-contaminated root canals of extracted human teeth. J Endod 2003; 29:576-9.

97. Shabahang S, Pouresmail M, Torabinejad $M$. In vitro antimicrobial efficacy of MTAD and sodium hypochlorite. J Endod 2003; 450-2.

98. Baumgartner JC, Johal S, Marshall JG. Comparison of the antimicrobial efficacy of $1.3 \% \mathrm{NaOCl} /$ Biopure MTAD to $5.25 \% \mathrm{NaOCl} / 15 \%$ EDTA for root canal irrigation. J Endod 2007; 33:48-51.

99. Beltz RE, Torabinejad M, Pouresmail M. Quantitative analysis of the solubilizing action of MTAD, sodium hypochlorite, and EDTA on bovine pulp and dentin. J Endod 2003; 29: 334-7.
100. Dunavant TR, Regan JD, Glickman GN, Solomon ES, Honeyman AL. Comparative evaluation of endodontic irrigants against Enterococcus faecalis biofilms. J Endod 2006; 32:527-31.

101. Haznedaroglu F, Ersev H. Tetracycline $\mathrm{HCl}$ solution as a root canal irrigant. J Endod 2001; 27:738-40.

102. Newberry BM, Shabahang S, Johnson N, Aprecio RM, Torabinejad M. The antimicrobial effect of Biopure MTAD on eight strains of Enterococcus faecalis: an in vitro investigation. J Endod 2007; 33:1352-4.

103. Davis JM, Maki J, Bahcall JK. An in vitro comparison of the antimicrobial effects of various endodontic medicaments on Enterococcus faecalis. J Endod 2007; 33:567-9.

104. Torabinejad M, Khademi AA, Babagoli J, Cho Y, Johnson WB, Bozhilov K, et al. A new solution for the removal of the smear layer. J Endod 2003; 29:170-5.

105. Torabinejad M, Cho Y, Khademi AA, Bakland LK, Shabahang S. The effect of various concentrations of sodium hypochlorite on the ability of MTAD to remove the smear layer. J Endod 2003; 29:233-9.

106. Kho P, Baumgartner JC. A comparison of the antimicrobial efficacy of $\mathrm{NaOCl} /$ Biopure MTAD versus $\mathrm{NaOCl} /$ EDTA against Enterococcus faecalis. J Endod 2006; 32:652-5.

107. Johal S, Baumgartner JC, Marshall JG. Comparison of the antimicrobial efficacy of $1.3 \% \mathrm{NaOCl} / \mathrm{BioPure}$ MTAD to $5.25 \% \mathrm{NaOCl} / 15 \%$ EDTA for root canal irrigation. J Endod 2007; 33:48-51.

108. Tay FR, Hiraishi N, Schuster GS, Pashley DH, Loushine RJ, Ounsi HF, et al. Reduction in antimicrobial substantivity of MTAD after initial sodium hypochlorite irrigation. J Endod 2006; 32:970-5.

109. Tay FR, Pashley DH, Loushine RJ, Doyle MD, Gillespie WT, Weller RN, et al. Ultrastructure of smear layer-covered intraradicular dentin after irrigation with BioPure MTAD. J Endod 2006; 32: 218-21.

110. Haapasalo M, Qian W, Portenier I, Waltimo T. Effects of dentin on the antimicrobial properties of endodontic medicaments. J Endod 2007; 33:917-25.

111. Clegg MS, Vertucci FJ, Walker C, Belanger M, Britto LR. The effect of exposure to irrigant solutions on apical dentin biofilms in vitro. J Endod 2006; 32:434-7.

112. Giardino L, Ambu E, Savoldi E, Rimondini R, Cassanelli C, Debbia EA. Comparative evaluation of antimicrobial efficacy of sodium hypochlorite, MTAD, and Tetraclean against Enterococcus faecalis biofilm. J Endod 2007; 33:852-5.

113. Svensäter G, Bergenholtz G. Biofilms in endodontic infections. Endod Topics 2004; 9:27-36.

114. Dai L, Khechen K, Khan S, Gillen B, Loushine BA,Wimmer CE, et al. The effects of QMiX, an experimental antibacterial rootcanal irrigant, on removal of canal wall smear layerand debris. J Endod 2011; 37: 80-4.

115. Giardino L, Ambu E, Becce C, Rimondini L, Morra M. Surface tension comparison of four common root canal irrigants and two new irrigants containing antibiotic. J Endod 2006; 32:1091-3. 
116. Zhang W, Torabinejad M, Li Y. Evaluation of cytotoxicity of MTAD using the MTT-tetrazolium method. J Endod 2003; 29:654-7.

117. Torabinejad M, Shabahang S, Bahjri K. Effect of MTAD on postoperative discomfort: a randomized clinical trial. J Endod 2005; 31:171-6.

118. Aranda-Garcia AJ, Kuga MC, Chavéz-Andrade GM, Kalatzis-Sousa NG, Hungaro Duarte MA, Faria G, et al. Effect of final irrigation protocols on microhardness and erosion of root canal dentin. Microsc Res Tech 2013; 76:1079-83.

119. Wang Z, Shen Y, Haapasalo M. Effectiveness of endodontic disinfecting solutions against young and old Enterococcus faecalis biofilms in dentin canals. J Endod 2012; 38:1376-9.

120. Ma J, Wang Z, Shen Y, Haapasalo M. A new noninvasive model to study the effectiveness of dentin disin- fection by using confocal laser scanning microscopy. J Endod 2011; 37:1380-5.

121. Wang Z, Shen Y, Haapasalo M. Effect of smear layer against disinfection protocols on Enterococcus faecalis-infected dentin. J Endod 2013; 39:1395-400.

122. Ballal NV, Tweeny A, Khechen K, Prabhu KN, Satyanarayan, Tay FR. Wettability of root canal sealers on intraradicular dentine treated with different irrigating solutions. J Dent 2013; 41:556-60.

123. Chandrasekhar V, Amulya V, Rani VS, Prakash TJ, Ranjani AS, Gayathri C. Evaluation of biocompatibility of a new root canal irrigant Q $\mathrm{Mix}^{\mathrm{TM}} 2$ in 1 - An in vivo study. J Conserv Dent 2013; 16:36-40.

124. Alkahtani A, Alkahtany SM, Mahmood A, Elsafadi MA, Aldahmash AM, Anil S. Cytotoxicity of QMix ${ }^{\mathrm{TM}}$ endodontic irrigating solution on human bone marrow mesenchymal stem cells. BMC Oral Health 2014; 14:27. 